\title{
Determinants of Farmer Participation in the Vertical Integration of the Rwandan Coffee Value Chain: Results from Huye District
}

\author{
Nkurunziza Issa ${ }^{1} \&$ Ngabitsinze Jean Chrysostome ${ }^{1}$ \\ ${ }^{1}$ Rural Development and Agricultural Economics, University of Rwanda, Rwanda \\ Correspondence: Nkurunziza Issa, Rural Development and Agricultural Economics, University of Rwanda, \\ Rwanda. E-mail: baissa27@gmail.com
}

Received: May 11, 2015 Accepted: June 22, 2015 Online Published: August 15, 2015

doi:10.5539/jas.v7n9p197 URL: http://dx.doi.org/10.5539/jas.v7n9p197

\begin{abstract}
This paper presents results on socio-economic factors influencing decision to participate in cooperative and intensity of coffee in Huye District of Rwanda. The analysis uses primary data collected from Huye district with representative sample size of 230 comprised both non-members and members of cooperatives. The study used Probit regression model to test the status of decision to participate and Tobit regression was used to determine the factors influencing the intensity of coffee. The results generally show that gender, education level, farm size, off-farm income, non-access to credits and non-record keeping are all important factors explaining decision to participate. On the other hand, off-farm income, no-access to credit, farm size, experience, farm under other crops cultivation and farm contract agreements found to influence the intensity. The paper concludes by suggesting strategic policy targeting to build stronger farmer' cooperatives. These should allow the farmers to have access on market, inputs, credit, farm contract, price stability and trainings. Thus improve coffee productivity in terms of quantity and quality in the study area.
\end{abstract}

Keywords: agricultural markets and marketing, cooperatives, agribusiness

\section{Introduction}

The coffee sector in Rwanda is vital to the country's economy by providing a source of foreign exchange and employment, especially for smallholder farmers in rural areas. Rwanda possesses excellent agro-ecological conditions for cultivation of Arabica coffee (Mujawamariya, 2007). Approximately 500,000 smallholder farmers grow Arabica coffee on a total area of 33,000 ha, each owning less than one hectare of land (OCIR-Café, 2008). While coffee is produced in all provinces of Rwanda, the high yielding areas are found along the shores of Lake Kivu in the western part of the country, as well as in the central and southern provinces (Rukazambuga, 2008).

Since 1995, the Government of Rwanda (GoR) began to target the production of specialty coffee for high-end markets. As a result coffee growers were encouraged to form and join cooperatives and building Coffee Washing Stations (CWS) throughout the country. CWSs are units specialized in depulping, washing and drying cherries, in order to obtain high quality coffee (fully washed coffee). Despite government efforts and the construction of CWSs, the production of fully washed coffee remains fairly low around $10 \%$ (Karl, 2008). The GoR has devoted its efforts to strengthening cooperatives to give farmers access to extension services, farm inputs, credit, markets and other services (Nambi, 2008). The table below shows the distribution of members and non-members of coffee cooperatives in all provinces of the country. 
Table 1. Membership of coffee farmers in the cooperatives in Rwanda in 2009

\begin{tabular}{llllll}
\hline Province & All Coffee Producers & Member of Cooperatives & $\mathbf{\%}$ & Non Member of Cooperatives & $\mathbf{\%}$ \\
\hline Northern & 58,858 & 21,557 & 37 & 37,300 & 63 \\
Southern & 133,781 & 17,058 & 13 & 116,722 & 87 \\
Eastern & 51,140 & 12,709 & 25 & 38,431 & 75 \\
Western & 143,150 & 28,370 & 20 & 114,779 & 80 \\
Kigali City & 7,277 & 890 & 12 & 6,386 & 88 \\
\hline Total & $\mathbf{3 9 4 , 2 0 6}$ & $\mathbf{8 0 , 5 8 4}$ & $\mathbf{2 1}$ & $\mathbf{3 1 3 , 6 1 8}$ & $\mathbf{7 9}$ \\
\hline
\end{tabular}

Source: OCIR-Café (2009).

Two reasons for the low production of fully washed coffee are the low level of participation of coffee farmers in cooperatives and the underutilization of coffee washing stations. According to National Agricultural Export Board (NAEB), in 2009, CWSs utilized only 43\% of their capacity (NAEB, 2010). According to OCIR-Café (2009) coffee census, Rwanda had 160 cooperatives in the coffee sector, with only $21 \%$ of the farmers being members nationwide. This low level of participation hinders coffee sector development because it makes it difficult for farmers to receive critical services.

This study was conceptualized as farmers' participation in vertical integration study in order to determine socio-economic factors that affect farmers' decision to participate in cooperatives. Ortmann and King (2007) explain that the idea of the cooperative is derived from the economics of vertical integration. According to Sexton and Iskow (1988) defined Agricultural cooperation as the coordination of producers to achieve mutual vertical integration. Cooperatives in developing countries are institutional arrangements, involved in the organization of often smallholder farmers with the advantages of reducing transaction costs of accessing input, output markets and improve power negotiation of smaller farmers' vis-à-vis large transaction partners (Kherallah \& Kirsten, 2001).

\subsection{Rwandan Coffee Supply Chain}

Rwanda has gradually established itself as a source of speciality coffee, sold internationally through fair trade (Mutwandwa et al., 2009). The coffee market chain in Rwanda is segmented into three types of coffee namely cherries, parchments and green coffee. 


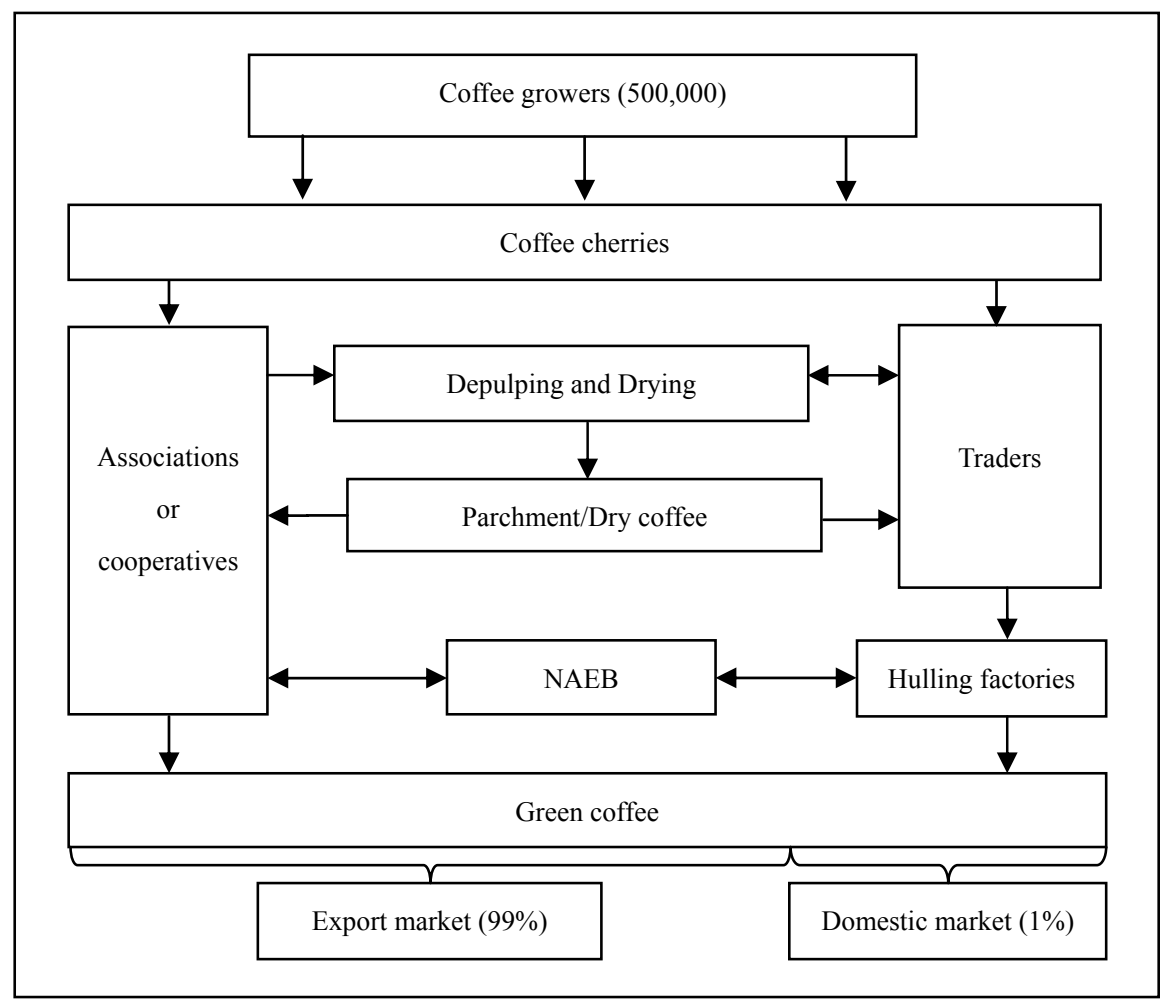

Figure 1. Coffee supply chain in Rwanda

Source: Adopted and modified from Murekezi (2003).

Selling cherries offers more benefits to farmers compared to selling parchments because of the relatively high prices (Murekezi, 2009). Parchment is mostly purchased by middlemen whereas the cherry is sold through either farmers' cooperatives or private processors (NAEB, 2010). After obtaining cherries, cooperatives and traders start transforming the product through a depulping and drying process (Figure 1 above). The subsequent transformation into green coffee via hulling (removing the parchment) is performed both by cooperatives (though a few own hulling machines) or by exporting companies A small proportion is roasted and domestically consumed and $99 \%$ of coffee is exported (OCIR-Café, 2008).

\subsection{Development of Farmers' Cooperative in Rwanda}

Individual smallholders in developing countries face numerous constraints in the marketing of their products resulting from high transaction costs in the market chain (Froukje et al., 2007). First, they have limited access to physical and financial resources. This restricts their opportunities to increase their scale of production in order to reduce transaction costs and to invest in efficiency increasing and value adding technologies. Secondly, smallholders have limited technical skills, no access to training on production and processing, or to information on market requirements. Lastly, individual farmers lack bargaining power and as a result there is no equal distribution of the value added among the actors in the market chain. Farmers' cooperatives or associations are often described as an effective way to solve most of these problems (Froukje et al., 2007).

Like many other African Countries, cooperatives were first introduced in Rwanda by the Belgians in the colonial period as instruments for driving the agenda of the government's socio-economic goals (Mukarugwiza, 2010). In the agricultural sector, African cooperatives were strictly controlled by the colonial administration to the point of fixing the prices that cooperatives could pay their members for their produce, which was lower than what private European entrepreneurs paid (Wanyama et al., 2009). At the time of independence in 1962, these cooperatives were mainly involved in social activities (e.g. mutual assistance and conviviality, offering health and life insurance, etc). After independence, the GoR used these cooperatives as mechanisms for implementing policies and development plans, thus becoming a tool for political control (MINICOM, 2006).

The government viewed cooperatives as institutions that help small farmers to produce cash crops such as coffee, tea and pyrethrum (Murekezi, 2009). After the genocide, different NGOs that supported the recovery of the 
country recognized the important role that cooperatives could play in social reconstruction and began to encourage the establishment of these organizations.

\subsection{Advantages of Cooperatives in Vertical Integration}

Farmer-based organizations may link producers to the market by helping them to overcome information deficiencies with respect to production standards and consumer preferences. These organizations can collect information about production technologies and consumer preferences and provide it to their members in the form of extension visits and demonstration sessions. This could be explained by the fact that farmers' associations have the potential to shorten the marketing chain by directly connecting small producers to markets; better coordinate production and marketing activities and facilitate farmer access to production inputs at fair prices (Shiferaw et al., 2006). According to Barton (2000) farmers form cooperatives with the goal to generate greater profits by obtaining inputs and services at lower costs than they could obtain elsewhere or that were not available, and by marketing the products at better prices or in markets that were previously not accessible.

Factors determining farmers' decision to join the cooperative are more complex in the case of perennial crop like coffee (which requires special care from the farm to the cup) than in the case of annual crop. This is because of the difficulties in securing the benefits associated with delivering high quality and quantity coffee, which is required at the international markets. In a study conducted on the determinants of small scale farmers' decision to join farmer-based organizations in Ghana, the results revealed that famer size, farming as a major occupation, access to credit and machinery services influenced farmers' decision to join farmer-based organization in the Eastern region of Ghana (Asante et al., 2011). Similarly, Frayne et al. (2008) find that education, farm size and gross income variables play important roles in determining the probability of participation. They revealed that smallholder farmers are likely to become members' of agricultural cooperatives than the larger farmers. This is associated with a study by Karli et al. (2006) who found that the probability of membership decreases with an increase in farm size. Furthermore, Okwoche et al. (2012) reported that farmers joined cooperative societies mainly to have access to credit. Conversely, Lerman and Ruben (2012) find that access to non-farm income encourages peasant farmers to join cooperatives because they are less exposed to risks.

In a study on socio-economic factors affecting rural women participation in productive cooperation, Aazamil et al. (2011) found that trust on cooperative staff, number of family members, economic motivation and land ownership were among socio-economic factors influenced the participation of women in cooperatives.

\subsection{Research Hypothesis}

$>$ Farmers' decisions are not influenced by socio-economic factors to participate in coffee cooperatives of Huye District.

$>$ The intensity of coffee production is not influenced by socio-economic variables.

\section{Methodology}

\subsection{Research Design}

A study design involving questionnaires and interviews with coffee farmers was adopted to enable an in-depth investigation of their participation in the vertical integration of the Rwandan coffee value chain. Primary data were collected through household surveys, which were supplemented by focus group discussions as well secondary data. The study was conducted in the Maraba, Kigoma, and Simbi sectors of Huye district in Southern Province of Rwanda. 


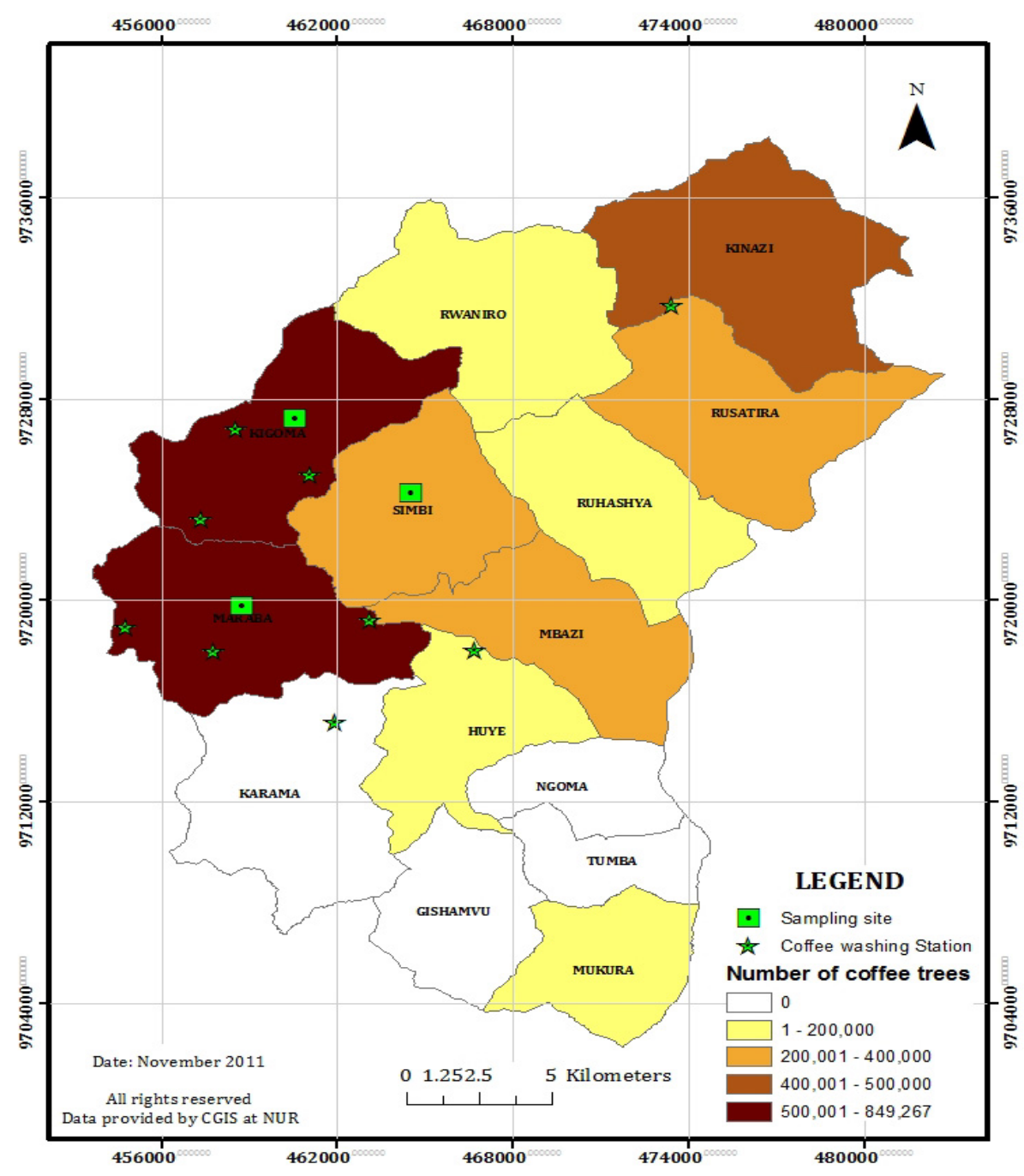

Figure 2. Study area and coffee trees distribution in Huye District

Source: Data from OCIR-Café (2009) modified by the author, 2012.

The selection of this area was based on suitability conditions for growing Arabica coffee as demonstrated by the number of coffee trees found in this area, as well as the number of CWSs and cooperatives present in the area.

The target population is composed of smallholders coffee farmers from Huye district in Southern province of Rwanda. Several sampling procedures were used to select the required sample size. The population size for Maraba, Kigoma, and Simbi sectors were 3834, 3794, and 2118 household, respectively (NAEB, 2010). A total of 230 farmers were selected from the three sectors of Huye district for the study using a required sample size formula proposed by Glenn (1992).

$$
n=\frac{\mathrm{N}}{1+\mathrm{N}(\mathrm{e})^{2}}
$$

Where, n: sample size; $\mathrm{N}$ : size of the farmers in cooperative; e: precision level chosen (for confidence interval of $95 \%$, equal to 5 percent). 
Table 2. The distribution of sample size per sectors of Huye District

\begin{tabular}{llllll}
\hline $\begin{array}{l}\text { Sector } \\
\text { name }\end{array}$ & $\begin{array}{l}\text { Numbers of coffee } \\
\text { coops members }\end{array}$ & $\begin{array}{l}\text { Sample size } \\
\text { coffee coops }\end{array}$ & $\begin{array}{l}\text { Numbers of } \\
\text { non-coops members }\end{array}$ & $\begin{array}{l}\text { Sample size of } \\
\text { non-coops members }\end{array}$ & $\begin{array}{l}\text { Sample size in total } \\
\text { per each sector }\end{array}$ \\
\hline Maraba & 1,898 & 87 & 4,025 & 40 & 127 \\
Kigoma & 1,222 & 56 & 1,408 & 14 & 70 \\
Simbi & 589 & 27 & 604 & 6 & 33 \\
Total & & $\mathbf{1 7 0}$ & & $\mathbf{6 0}$ & $\mathbf{2 3 0}$ \\
\hline
\end{tabular}

Source: OCIR-Café (2009).

A stratified sampling technique was employed to select coffee farmer, of which 170 were cooperative members and 60 were non-members.

\subsection{Data Collection}

Both qualitative and quantitative data were collected with the help of enumerators that were supervised by the researchers. The data gathered from the farmers included social and economic characteristics such as education level, access to credit, off farm income, coffee yield, farm net income, gender, as well as agronomic challenges that smallholder farmer's faced in their operation. To improve the reliability of the data collected in the household survey, more consultation with cooperatives members and non-members were held using a focus group discussion approach. The focus group was comprised of 12 coffee growers who were selected by local cooperative leaders. This focus group was used to get detailed information on the various socio-economic factors affecting farmers' decision to participate in coffee cooperatives in Huye district of Rwanda.

\subsection{Analytical Models}

\subsubsection{Farmers' Choice to Participate}

Before using probit model, descriptive statistics (percentages, means, fisher-test, chi-square and t-test) were carried out to describe socio-economic of coffee cooperative members and non-members at the time of the study. Probit model was used to determine socioeconomic factors influencing farmers' choice to participate in coffee cooperatives. Probit model was chosen because it allows estimating maximum likelihood of socioeconomic factors influencing farmers' choice to participate in coffee cooperatives. According to Sanchez (2005) the Probit model to analyse the decision to participate in cooperatives is estimated by means of the following Probit regression. Probit model stand for cumulative normal probability function.

$$
\begin{aligned}
\mathrm{P}(\mathrm{yes} / \mathrm{no})= & \beta_{0}+\beta_{1}(\text { Edu })+\beta_{2}(\text { Gender })+\beta_{3}(\text { Exp })+\beta_{4}(\text { Occ })+\beta_{5}(\text { familysize })+\beta_{6}(\text { farmsize }) \\
& +\beta_{7}(\text { Offfarminc })+\beta_{8}(\text { Accessloan })+\beta_{9}(\text { Keeprec })+\beta_{10}(\text { Trust })+\beta_{11}(\text { sellprc })+\mu_{i}
\end{aligned}
$$

Where: $\mathrm{P}(\mathrm{yes} / \mathrm{no})$ is the probability of participation by members and non-members of coffee cooperatives, $\beta o$ is the intercept; $\beta_{\text {in }}(1,2,3,4, \ldots n)$ is the vector of parameters and $(E d u),($ Gender), ... (sellprc) are exogenous explanatory variables and $\mu_{i}$ is the error term.

Many authors have used probit model in their studies. Beyene (2008) used probit model to account for the simultaneity of participation decisions of both male and female members of farm households. Matshe and Trevor (2003) had used probit model to determine the characteristics that influenced the probability that a farm household member will participate on off farm work.

\subsubsection{The Intensity of Expansion}

To determine factors associated with coffee production intensity, Tobit regression model was chosen for this analysis because it can measure the probability and intensity of coffee land (Tobin, 1958). The model was generally formulated by Cragg (1971) and applied in many studies including (Wakulira, 2005) estimated factors influencing hulling coffee among farmers in Masaka District, Uganda. Specified the model as:

$$
\begin{aligned}
\text { Land share }(0 \text { to } 1)= & \left.\left.\beta_{0}+\beta_{1} \text { (Gender }\right)+\beta_{2} \text { (Accessloan) }+\beta_{3} \text { (Farmsize }\right)+\beta_{4}(\text { Offfarminc })+\beta_{5} \text { (Familysize) } \\
& \left.+\beta_{6}(\text { Educ })+\beta_{7}(\text { Exp })+\beta_{8} \text { (contractfar }\right)+\beta_{9}(\text { Othercrops })+\mu_{I}
\end{aligned}
$$

Where $P$ (land share) is the proportion of coffee intensity, $\beta_{0}$ is the intercept, $\beta_{i n}(1,2,3, \ldots n)$ is the vector of parameters to be estimated and $\mu_{\mathrm{i}}$ is a vector of independently error terms with zero mean and Constance variance $\delta^{2}$. A vector of explanatory variables are, (Gender), (Accessloan), (Farmsize), ... (Othercrops). 


\section{Results}

\subsection{Demographic Characteristics of Farmers in Huye District}

Our data show that the majority of individuals engaged in coffee farming were male (Table 3). Personal communications with women farmers revealed that females were more interested in cultivating food crops that provide cash in a relatively shorter period of time. While the majority of the farmers in the study area had at least a primary education, a significant proportion had received no formal education. The majority of farmers reported farming as their main occupation, a fact that is corroborated by the lack of non-farm opportunities available in the area. Since Kigoma and Simbi are serviced by a few commercial banks, farmers in those sectors reported having more access to credit than those in Maraba.

Table 3. General descriptive of farmers' characteristics in three sectors of Huye District

\begin{tabular}{lllll}
\hline \multicolumn{4}{c}{ Comparison of farmers' characteristics in three sectors of Huye district in \% $(\mathrm{n}=230)$} \\
\hline Characteristic & & Maraba & Kigoma & Simbi \\
\hline Gender & Male & 52 & 61 & 55 \\
& Female & 48 & 39 & 45 \\
Education level & No formal education & 31 & 24 & 6 \\
& Primary education & 64 & 66 & 85 \\
Main occupation & Secondary education & 5 & 10 & 9 \\
& Farming & 79 & 86 & 91 \\
& Commerce & 4 & 7 & 6 \\
& Paying job & 17 & 7 & 3 \\
Access to loan & Craftman & 1 & 0 & 0 \\
& Yes/taken & 39 & 60 & 67 \\
\hline
\end{tabular}

Source: Survey data.

\subsection{Sources of Credit for the Coffee Farmers in Huye District}

Farmers in Huye district reported obtaining credit from various sources, including financial institutions, cooperatives, relatives, friends, as well as other famers. Findings show that the main source of credit for cooperative members were from their own cooperatives as well as through micro financing. For example, cooperatives contributed $48 \%, 31 \%$ and $33 \%$ of loans given to the members in Maraba, Kigoma and Simbi sectors, respectively, while farmers who obtained credit from micro financing were $27 \%, 36 \%$ and $27 \%$, in the three districts respectively. Non-cooperative members in Maraba and Kigoma reported obtaining credit through micro financing ( $44 \%$ and $57 \%$ respectively), while farmers in Simbi obtained all of their loans rom either relatives or other farmers.

These findings show that accessibility to credit from formal sources, such as commercial banks, is low. The low availability of credit could be explained by a lack of farmer knowledge on how to open bank accounts, lack of information regarding procedures for accessing credit, collateral requirements and a lack of commitment by the small-scale farmers to take risks. According to Agnet (2004) the complex mechanism of commercial banks are least understood by small-scale farmers and hence this limits their access to credit. The inaccessibility of credit for small scale farmers to buy required farm inputs could be a major limiting factor to increasing coffee production.

\subsection{Comparison between Participant and Non-Participants}

Factors thought to influence farmer participation in cooperatives are reported for both member and non-member farmers in Table 4. Chi-square and t-tests reveal that both groups of farmers are statistically different from each other with regards to gender, access to loans, yield, trust, off-farm income, record keeping and farm size. These results suggest that cooperative member farmers are mostly male, have a lower level of education, more access to loans and reported higher yields than their non-member counterparts. 
Table 4. Univariate results of socio-economic factors influencing farmers' decision to participate in coffee cooperatives

\begin{tabular}{|c|c|c|c|c|}
\hline Characteristic & & Member (\%) & Non-member (\%) & Test \\
\hline \multirow[t]{3}{*}{ Education level } & No formal education & 40 & 15 & 0.183 \\
\hline & Primary education & 56 & 68 & \\
\hline & Secondary education & 4 & 17 & \\
\hline \multirow[t]{2}{*}{ Gender } & Male & 62 & 35 & $0.001 *$ \\
\hline & Female & 38 & 65 & \\
\hline \multirow[t]{5}{*}{ Experience } & $<5$ years & 20 & 17 & 0.309 \\
\hline & $6-10$ years & 10 & 22 & \\
\hline & $11-15$ years & 16 & 15 & \\
\hline & $16-20$ years & 19 & 18 & \\
\hline & Over 20 years & 35 & 38 & \\
\hline \multirow[t]{2}{*}{ Access to loan } & Yes/taken & 46 & 27 & $0.022 *$ \\
\hline & Not/taken & 54 & 73 & \\
\hline \multirow[t]{4}{*}{ Trust } & Not & 0 & 22 & $0.001 *$ \\
\hline & Low trust & 15 & 68 & \\
\hline & Medium trust & 62 & 10 & \\
\hline & High trust & 23 & 0 & \\
\hline \multirow[t]{2}{*}{ Off-farm income } & Yes & 42 & 20 & $0.030 *$ \\
\hline & No & 58 & 80 & \\
\hline \multirow[t]{3}{*}{ Keeping records } & Yes/kept & 53 & 32 & $0.004 *$ \\
\hline & Not/kept & 47 & 68 & \\
\hline & & Mean & Mean & t- test \\
\hline Family size & & 6 & 5 & 0.118 \\
\hline Farm size & & 0.5 & 0.8 & $0.010 *$ \\
\hline Yield & & 759 & 635 & $0.000^{*}$ \\
\hline Selling Price & & 311 & 303 & 0.435 \\
\hline Net farm income & & $2.23 \mathrm{E} 5$ & $1.93 \mathrm{E} 5$ & $0.000 *$ \\
\hline
\end{tabular}

Note. $\mathrm{n}=230 ; *$ denotes significance at the 0.05 level; $\alpha=0.05$.

Source: Survey data.

\subsection{Socio-Economic Determinants of Farmer Participation in Coffee Cooperatives}

A probit regression analysis was used to determine which socio-economic factors influence farmers' decision to join coffee cooperatives. Results are presented in Table 5. Model diagnostics indicate that that all variables are jointly significant at the 0.05 level. 
Table 5. Maximum likelihood estimate of the choice of cooperative membership as related to socio-economic characteristics of coffee farmers in Huye district, Rwanda

\begin{tabular}{lll}
\hline Cooperative membership & Coef. & Std. Err. \\
\hline Male & $0.464^{* *}$ & 0.212 \\
Education & $-0.708^{*}$ & 0.408 \\
Farming_occupation & 0.024 & 0.461 \\
Family_size & -0.068 & 0.056 \\
Farm_size & $3.429^{* * *}$ & 1.108 \\
Farm_size & $-1.471^{* * *}$ & 0.535 \\
Selling_price & 0.002 & 0.005 \\
Farming_experience & 0.018 & 0.015 \\
Offfarm_income & $0.891^{* * *}$ & 0.257 \\
No_Credit_Access & $0.482^{* *}$ & 0.230 \\
No_Record_Keeping & $0.590^{* * *}$ & 0.223 \\
Constant & 1.038 & 1.667
\end{tabular}

Observation $=230$

LR Chi-squire $=74.93$

Log likelihood $=-94.544833$

Note. $*: \mathrm{p}<0.1 ; * *: \mathrm{p}<0.05 ; * * *: \mathrm{p}<0.01$.

\subsection{Influence of Gender Head of Household on Cooperative Membership}

Male headed the household was found positively and significantly influencing decision to participate in coffee cooperatives. This implies that male headed households are more likely to join and participate in farmer's cooperative than female headed households. Likely explanation for this is that that male farmers' have free time and are the ones who mostly attend meetings on coffee campaigns unlikely women who are busy with family duties. This reflects that participation of male in the meetings can enhance their awareness on the importance of joining cooperative than female. In a study conducted on why some rural people become members of agricultural cooperatives while others do not in Ethiopia (Nugussie, 2009), results showed that the probability of male headed households to become member of the cooperatives were $22 \%$ higher female headed households. Similarly to Fanaye and Thomas (2012) who showed that participation in agricultural cooperatives for both male and female headed households were $76 \%$ and $24 \%$ respectively.

\subsection{Influence of Households Education Level on Cooperative Membership}

Education level of headed household was found negatively and significantly influencing decision of a farmer to become cooperative member. These results are inconsistent with the expectation since education provides farmers with more information pathways (Faturoti et al., 2006). Higher level of formal education equips farmers with more knowledge and skills hence facilitate the awareness of importance to work in a cooperative. However, the implication of these results is that a farmer with lower level of education is likely to join cooperatives than the farmers with high level of education. This could be because the educated farmers are usually in formal employment or are in large scale production while the ones with low education qualifications are usually smallholder farmers who joins the cooperatives in order to put together their individual efforts for survival and get a high bargaining power for inputs as well as markets for their produce. These results agree with those of Steven (2012) in a survey conducted in Kenya's coffee cooperatives found that only $2 \%$ of cooperative members had college or university education, while the rest had primary and no formal education. However, the lack of many educated members limits the ability of cooperative to negotiate profitable deals with international coffee retailers.

\subsection{Influence of Farm Size on Cooperative Membership}

Farm size owned by head of household found positively and significantly influencing famer' decision to join cooperatives. But on the other hand when the size of land continues to increase to $1 \%$ of farm size, decrease the 
probability of joining cooperative by $-1.471 \%$. These results are in consistent with the findings showed that non-members had average farm size equivalent to 0.8 hectare while members had 0.5 hectare. These explain that farmers with small farm sizes are most likely to join cooperatives be because they may wish to benefit from cash, input subsidies, and service provided by the agricultural cooperatives since the risks associated with intensive high-return crops are high. The results concur with a study of Karli et al. (2006) in the South Eastern Anatolian Region of Turkey which reported that the probability of the membership decreases with the increase in the farm size. Similarly to the study of Tursinbenk and Karin (2010), Mussie et al. (2001) and Gockowski and Ndoumbe (2004) found a negative relationship between farm size and decision to join or adopt farmer based organization.

\subsection{Influence of off Farm Income on Cooperative Membership}

The findings revealed that off farm income positively and significantly influenced the participation of farmers in cooperatives. These results imply that likelihood of becoming cooperative member increased with the availability of incentives such as employment, etc. This is explained that cooperatives employ its members as permanent staff or temporary jobs for instance during coffee processing period to undertake different activities such as cherries sorting, floating, pulping, drying, grading, transporting, packaging and so on. This can show why off farm income is significantly associated with cooperative membership; in fact this earning opportunity for the cooperative members and their family members can influence the decision of farmers' being cooperative members. This finding is consistent with the results of a study by Murekezi (2003) who noted that off-farm income opportunities and formal wages were associated with increasing household income and thus be able to be affiliated with cooperatives. Similarly, in a study of Frayne et al. (2008) reported that members of new generation cooperatives in northern plains had more off farm income that non-members, and had higher net worth than non-members.

\subsection{Influence of Access to Credit on Cooperative Membership}

Farmers who have no access to credit show a positive and significant decision to participate in cooperatives. Cooperatives are one of major source of credits for small scale; therefore small farmers are more likely to become members in order to have access to credit loan without collateral requirement and high interest rate once they do not have any other source of income apart from farming. This result is consistent with Nzomoi et al. (2007) who found a positive relationship between access to loan and decision to join a farm based organization. Similarly to a study conducted on technical efficiency in Kenyan's maize production the results showed that farmers who accessed agricultural credit through cooperatives recorded higher level of agricultural productivity thus increasing the participation than those that did not (Kibaara, 2006).

\subsection{Influence of Keeping of Farm Records on Cooperative Membership}

The results revealed a significant relationship between no keeping records and decision to join cooperatives. This means that the members of cooperatives had high chance of keeping record than non-members. It can be explained by the fact that during harvesting season, when farmers want to deliver their cherries to coffee washing station owned by their cooperatives, they have to register the quantity supplied and keep a copy for later claim of payment. Moreover, a farmer that kept records was more likely to use the records for monitoring, planning, selection decision and improving management efficiently than those who do not keep records. These results concur with those of a study by Hoffman (1996) who concluded that well managed small farms, based on farm records, are better able to compete in per unit profitability with farms many times larger.

\subsection{Factors Influencing Coffee Intensity in Huye District of Rwanda}

A tobit model framework was employed to explore the factors influencing the intensity of coffee growing (expansion). Results reveal six factors significantly influencing the intensity of coffee (Table 6). Model diagnostics indicate that that all variables are jointly significant and results show that six factors significantly influence the intensity of coffee growing. 
Table 6. Factors influencing the intensity of coffee growing in Huye District of Rwanda

\begin{tabular}{lll}
\hline Tobit regression & & \\
\hline land_coffee & Coef. & Std. Err. \\
\hline Offfarm_income & $0.053^{* * *}$ & 0.017 \\
No Credit_Access & $0.035^{* *}$ & 0.017 \\
Farm_size & $0.306^{* * *}$ & 0.082 \\
Male & 0.006 & 0.016 \\
Education & 0.027 & 0.027 \\
Family_size & -0.003 & 0.004 \\
Experience & $0.002^{*}$ & 0.001 \\
Other_crops (land) & $-0.060^{*}$ & 0.034 \\
Farm_contract & $0.036^{* *}$ & 0.017 \\
Sigma & 0.119 & 0.006 \\
\hline Observation= 230 & & \\
LR Chi-squire= 155.66 & & \\
Log likelihood $=-159.74$ & & \\
\hline $\mathrm{p}<0.1 ; * *: \mathrm{p}<0.05 ; * * *: \mathrm{p}<0.01$. & & \\
\hline
\end{tabular}

\subsection{Influence of Household off Farm Income on Coffee Intensity}

Off farm income of head of households found to positively and significantly influencing the intensity of coffee growing. This result implies that households getting off farm income were more likely to invest in activities regarding expansion of coffee production than head of households without off farm income. This meant that off-farm income can be used to buy additional land, to buy food, or farm inputs. These results agrees with those of De Janvry et al. (2005) who noted that the income obtained from non-farm activities helps enhance the investment capacity in farm activities, mitigate income fluctuations and thus favour household agriculture production as well. Likewise, Salgado (1994) found that nonfarm income presents important sources to finance land acquisition and the purchase of farm inputs and food.

\subsection{Influence of Household Gender on Coffee Intensity}

Gender of the household head significantly influenced the intensity of coffee growing. The male headed households were more likely to have coffee intensity than female headed households. This could be explained by the fact that female heading households may have smaller farm size compared to male who can used it for coffee intensification. The implication of this is the issue of land inheritance whereby female had not right to own land from her parents. This result is consistent with the findings of Ekenta et al. (2012) revealed that $74 \%$ of males had farm size of 4 hectares and above against $16 \%$ of females. The same authors found that land inheritance $75 \%$ is the most common ownership structures among males while females $67 \%$ purchased land used in agricultural production. This result agrees with findings of (Onyemauwa, 2012; Osugiri, 1996). These results also agree with Okwoche et al. (2012) who noted that females are often married to the males and so might not out rightly own the lands. Similarly Adesina et al. (2000) pointed out that male headed households tend to be more likely to adopt innovation in their lands than female headed households because African women are marginalized and have low access to critical resources such as land and are also deprived of education opportunities.

\subsection{Influence of Farming Experience on Coffee Intensity}

Farming experience of head of household was found to positively and significantly influencing the intensity of coffee. The results imply that the more the years of farming experience a household has, the more the likelihood of the household to expand their coffee production. Farmers with more years of farming experience in growing coffee could be easier in comprehending the accrued benefit from coffee better than the farmers with less years of farming experience hence expanding land for coffee production. These results are in agreement with those of Elzo et al. (2010) who noted that more experienced farmers fed and managed their herds better, produced more milk, received higher revenues and expanded their production better than less experienced farmers. According to 
Mishra et al. (2004) old farmers have more experience and can better allocate resources where they are needed and keep them fully utilized.

\subsection{Influence of Land under Other Crops on Coffee Intensity}

Land occupied by other crops such as beans, sweet potato, Irish potato, cassava, maize were found to negatively and significantly influence the intensity of coffee. The implication of this result is that the crops mentioned above get into competition of land with coffee farming, hence negative effect on coffee intensity because farmers need to produce more food in a short period of time. A $1 \%$ increase of farm size under other crops cultivation decreases the probability of coffee intensity by $-0.060 \%$ all else held constant. Mckay and Loveridge (2005) who said that as the production of beans, cassava and Irish potatoes increased the production of cash crops such as coffee and banana declined.

\subsection{Influence of Farm Contract on Coffee Intensity}

Having a farm contract showed a positive influence on coffee intensity. It implies that the farmers who have contract agreement with the buyers can easily adopt coffee intensity because they already have the market for their coffee, what remains is to expand the size of land that will allow them to increase quantity and quality of their produce. This agrees with Guo et al. (2005), in the study of contract farming in China, found that farmers identify contract farming arrangements as key advantage to obtain price stability, market access, and technical assistance to improve quality. Therefore contract farming given to the farmers can ensure increase of productivity through the intensity.

\section{Conclusions and Policy Recommendations}

\subsection{Conclusions}

Although the role of cooperatives are not seen by the coffee growers in Rwanda based on smaller number of the famers who have joined them, there are a quite numbers of socio-economic contribution that the cooperative bring to their members. The results revealed that members of cooperative had average yield of coffee equivalent to $759 \mathrm{kgs} / \mathrm{ha}$ compared to $635 \mathrm{kgs} / \mathrm{ha}$ for non-members; had annual average farm net income corresponding to 223,000 Rwfs and 193,000 Rwfs for members and non-members respectively.

This study has shown factors that influence decision to join cooperatives whereby; male, farm size, off farm income, non access to credit, non keeping records found positively influencing decision to join cooperatives while education and large farm size showed to negatively influence the decision to join cooperatives. These results reflect that coffee growers need much training on role of cooperatives and leaders of cooperatives should have the capacity of leading small farmers.

The results show the factors influencing the intensity of coffee that off farm income, non credit access, farm size, experience and farm contract found positively influencing the intensity of coffee while land under other crops cultivation was found negatively influencing the intensity coffee.

\subsection{Recommendations}

The cooperatives management committee together with the government should organize trainings on gender sensitivity in coffee sectors in order to increase level of participation of female in the coffee cooperatives.

Cooperatives should put in place strategies that will attract educated farmers to join cooperatives by minimizing number of meetings during working days.

Govt should put down strategies for improving education levels; and training of farmers on coffee production through covering transport costs for Rwandan coffee experts who are willing to train farmers on how high quality coffee can be produced.

Agricultural extensions agents should create more awareness on availability of credit to the farmers and its impact in improving agricultural productivity.

The government and its development partners in coffee sector and farmer' cooperatives should encourage the farmers to sell their coffees to the buyers provide farm contract of agreements.

Coffee growers in the study area should intercrop coffee trees with annual crops (beans, soya beans) that do not affect quality and quantity of coffee produced in order to maintain farm size under coffee production.

\section{Reference}

Aazamil, M., Homan, S., \& Karim, N. M. (2011). Socio-economic Factors Affecting Rural WP in Productive Cooperation: Case Ctudy of Paveh Ball-Making Cooperative. University of Tehran, Iran. 
Adesina, A., Mbila, D., Nkmleu, G., \& Endamana, D. (2000). Econometrics Analysis of the Determinants of Adoption of Alley Farming by Farmers in the Forest Zone of Southwestern Cameroon. Agriculture, Ecosystem and Environment, 80(3), 255-265. http://dx.doi.org/10.1016/S0167-8809(00)00152-3

Agnet, N. (2004). Making Farm Credit Work for the Small-scale Farmers.

Asante, B., Sefa, V., \& Saprong, D. (2011). Determinants of Small Scale farmers' decision to join a farmer based organizations in Ghana. African Journal of Ahricultural Research, 6(10), 2273-2279.

Barel, M., \& Jacquet, M. (1994). Coffee Quality: Its Causes, Appreciation and Improvement. Plant Rech. Develop.

Barton, D. (2000). What is a Cooperative? Unpublished paper, Kansas State University, USA.

Behailu, W., Abrar, S., Nugussie, M., \& Indris, S. (2008). Coffee Processing and Quality Research in Ethiopia. In Proceedings of a National workshop four Decades of Coffee and Development in Ethiopia (pp. 307-317). AIAR Addis Ababa, Ethiopia.

Beyene, D. (2008). Determinants of Off-Farm Participation Decision of Farm Households in Ethiopia. Agrekon, 47(1), 140-152. http://dx.doi.org/10.1080/03031853.2008.9523794

Cragg, J. (1971). Some Statistical Models for Limited Dependent Variables with Application to the Demand for Durable Goods. Econometrica, 39, 829-844. http://dx.doi.org/10.2307/1909582

De Janvry, A., Sadoulet, E., \& Zhu, N. (2005). The Role of Non-farm Incomes in Reducing Rural Poverty and Inequality in China. Department of Agricultural and Resource Economics, UCB, UC Berkeley.

Ekenta, M., Aderonke, B., \& Keyode, A. (2012). Gender Analysis of Land Ownership Structure andAgricultural in Imo State, Nigeria. Journal of Economics and Sustainable Development, 3(9).

Elzo, A., Suwanasopee, T., Yeamkong, S., \& Koonawootrittriron, S. (2010). Effect of Experience, Education, Record, labor and Decisin Making on Monthly Milk Yield and Revenue of Dairy Farms Supported by a Private Organization in Central Thailand. Asian-Aust. J. Anim. Sci., 23(2), 814-824.

Fanaye, T., \& Thomas, W. (2012). Women's Participation in Agricultural Cooperatives in Ethiopia. International Food Policy Research Institute (FPRI).

Faturoti, O., Emah, N., Isife, I., Tenkouano, A., \& Lemchi, J. (2006). Prospects and Determinants of Adoption of IITA Platain and Banana Based Technologies in Three Niger Delta States of Nigeria. African Journal of Biotechnology, 5(14), 1319-1323.

Frayne , O., Theron, K., \& Gary, G. (2008). New Generation Cooperative Membership: How do Members differ from Non-Members?

Froukje, K., Menno, K., \& Alessandra, G. (2007). Collecting Action for Small-Scale Producers of Agricultural Biodiversity products. CAPRi Working Paper No. 71.

Glenn, I. (1992). Sampling the Evidence of Extension Program Impact. Programme Evaluation and Organizational Development. PEOD-5. IFAS, University of Florida.

Gockowski, J., \& Ndoumbe, M. (2004). The adoption of Intensive Monocrop Horticulture in Southern Cameroon. Journal of Agricultural http://dx.doi.org/10.1111/j.1574-0862.2004.tb00188.x

Guo, H., Jolly, R. W., \& Zhu, J. (2005). Contract Farming in China. Supply Chain or Ball and Chain? Paper presented at the 15th Annual Food and Agribusiness. Symposium/IAM, AT Chicago.

Hoffman, R. (1996). Size and Profitability, It's Better to be Good than Big, but you can't beat Good and Big. Farm Journal, 2-3.

ITC. (2002). Coffee Exporters' Guide. Geneva: UNCTAD/WTO.

Karl. (2008). Coffee Rwanda-Supplier of Gourmt, Fair Trade Rwanda Coffee. Retrieved January 21, 2014, from http://www.coffeerwanda.com/coffee.html

Karli, A., Bilgic, A., \& Celik, Y. (2006). Factors Affecting Farmers' Decision to Enter Agricultural Cooperatives Using Random Utility Model in the South Eastern Anatolian Region of Turkey. Journal of Agricultural and Rural Development in the Tropics and Subtropics, 107(2), 115-127. 
Kherallah, M., \& Kirsten, J. (2001). The New Institutional Economics: Applications forAgricultural Policy Research in Develepment Countries. Discussion paper. International Food Policy Research Institute (IFRPI), Markets and Structural Studies Division.

Kibaara, W. (2006). Technical Effency in Kenyan's Maize Production: An Application of the Stochastic Frontier Approach. Collins/Colorado: Colorado State University.

Lerman, Z., \& Ruben, R. (2012). Why Nicaruguan Peasants Remain in Agricultural Production Cooperatives (pp. 1-28). American Agricultural Economics Association.

Lorey, T., Bertrand, F., Charmetant, B., \& Dufour, P. (2006). Genetics of Coffee Quality. Danish Institute for International Studies Working Paper, Copenhagen.

Matshe, I., \& Trevor, Y. (2003). Off-farm Labour Allocation Decison in Small-Scale Rural Households in Zimbabwe. University of Manchester, UK.

Mckay, A., \& Loveridge, S. (2005). Income and Nutritional Outcomes in Rwanda's Rural Areas, 1990 and 2000. Food Security Research Project/MINAGRI. Policy Synthesis. No. 74.

MINICOM. (2006). National Policy on Promotion of Cooperatives Sector. Republic of Rwanda, Kigali.

Mishra, K., Fisseha, T., \& Carmen, L. S. (2004). The Impact of pParticipation in Cooperatives on the Success of Small farms. Journal of Agribusiness, 22(1), 31-48.

Mitchell, W. (1998). Cultivation and Harvesting of the Arabica Coffee Tree. In E. J. Clarke (Ed.), Coffee: Agronomy. New York: Elservier Applied Science.

Mujawamariya, G. (2007). Cooperatives in the Development of Coffee Farming in Rwanda: Membership Choice From a Transaction Cost Economics Persepective. Wageningen University.

Mukarugwiza, E. (2010). The Hope for Rural Transformation: A Juvenating Cooperative Movement in Rwanda. International Labour Organization.

Murekezi, A. K. (2003). Profitability Analysis and Strategic Planning of Coffee Processing and Marketing in Rwanda. Michigan State University.

Murekezi, A. K. (2009). Essay on the Effects of Coffee Market Reforms, Supply Chains, and Income Improvement in Rwanda. Michigan State University.

Mussie, A., Mwanga, J., Mwangi, W., Verkuijl, H., Mungi, R., \& Elang, A. (2001). Adoption of Improved Wheat Technologies by Small Scale Farmers in Mbeya District, Southern Highland, Tanzania. International Maize and Wheat Improved Centre (CIMMYT) of The United Republic of Tanzania.

Mutwandwa, E., Karuma, N., Rusatira, E., Kwiringirimana, T., Patrice, M., \& Foti, R. (2009). Analysis of Coffee Export Marketing In Rwanda: Application of the Boston Consulting Group Matrix. African Journal of Business Managament, 2(4).

NAEB. (2010). Annual report. Kigali-Rwanda.

Nambi, V. (2008). Rwanda's Cooperative Strategy against Poverty. Kigali-Rwanda.

Nugussie, Z. (2009). Why Some Rural People Become Members of a Agricultural Cooperatives while Others do not. Mekelle University, Ethiopia.

Nzomoi, J., Byaruhanga, J., Maritin, H., \& Omboto, P. (2007). Determinats of Technology Adoption In The Production of Horticultural Export Produce in Kenya. Afri. J. Bus. Management, 1(5), 129-135.

OCIR-Café. (2008). Rwanda Industry Review. Kigali-Rwanda.

OCIR-Café. (2009). National coffee Census and Assessment of the Present State of the Coffee in Rwanda. Kigali-Rwanda.

Okwoche, V., Osogura, B., \& Ckukwudi, P. (2012). Evaluation of Agricultural Credit Utilization by Cooperative Farmers in Benue State of Nigeria. Eurapean Journal of Economics, Finance and Administrative Sciences, 47, 18-27.

Onyemauwa, S. (2012). Analysis of Women Participation in Cassava Production and Processing in Imo State, South-East Nigeria. Journal of Economics and Sustainable Development, 3(5).

Ortmann, F., \& King, R. (2007). Agricultural Cooperatives II: Can They Facilitate Access of Small-Scale Farmers in South Africa to Input Out Product Markets? Agrkon, 46(2). 
Osugiri, I. (1996). Effect of Population on Agricultural Production in Imo State. Masters Thesis, University of Nigeria Nsukka, Nigeria.

Rukazambuga, D. (2008). The National Integrated Pest Management Framework For Rwanda. Kigali, Rwanda.

Salgado, R. (1994). Elmercado de Tierras en Honduras. Wisconsin: Tegucigalpa/Medison, NI: CEDOH for POSCAE and Land Tenure Centre.

Sanchez, V. (2005). The Determinants of Rural Non-Farm Employement and Incomes in Bolivia (pp. 15-16). A Thesis, Master of Science Department of Agricultural Economics, Mishigan State University.

Sexton, R., \& Iskow, J. (1988). Factors Critical to the Success or Failure of Emerging. Agricultural Cooperatives. Giannini foundation information series No. 88, Berkeley.

Shiferaw, B., Obare, G., \& Muricho, G. (2006). Rural Institutions and Producer Organizations in Imperfect Markets: Experience from Producer Marketing Groups in Sem-Arid Eastern Kenya. ICRISAT.

Söndahl, R., Van der Vossen, H., Piccin, M., \& Anuetto, F. (2005). The plant. In R. Viani (Ed.), Espresso Coffee: The Chemistry of Quality (2nd ed.). Academic press Ltd, London.

Steven, G. (2012). Kahawa Yetu- our coffee: A Need for Better Organizational Capacity in Kenya's Coffee Cooperatives. Case Study of New Gatanga Coffee Cooperative Society, Kenya: The University Guelph.

Tobin, J. (1958). Estimation of Relationships for Limited Dependent Variables. Econometrica, 26, 24-36. http://dx.doi.org/10.2307/1907382

Tursinbenk, S., \& Karin, L. (2010). Do Institutional Incentives Matter for Famers to Join Cooperatives. A Comparison of Two Chinese Regions with Different Levels of Economic and Social Development. Leibniz Institute of Agricultural Development in Central and Eastern Europe.

Van der Vossen, H. (2005). A Critical Analysis and Economic Sustainability of Organic Coffee Production (pp. 461-467). Plant breeding and Seed Consultant, 1606 CA 18 Venhuizen, The Netherland.

Wakulira, M. (2005). Factors Influencing Hulling of Coffee Among Farmers in Masaka District, Uganda (pp. 19-22). Thesis, Makerere University, Uganda.

Wanyama, D. (2009). Reinventing the Wheel? African Cooperatives in a Liberalized Economics Environment. Annuals of Public and Cooperative Economic, 80(3), 361-392. http://dx.doi.org/10.1111/j.1467-8292.2009.00390.x

\section{Copyrights}

Copyright for this article is retained by the author(s), with first publication rights granted to the journal.

This is an open-access article distributed under the terms and conditions of the Creative Commons Attribution license (http://creativecommons.org/licenses/by/3.0/). 